\title{
Repetitive Albania in Time Magazine, a Longitudinal Case Study: 1923-2013
}

\section{Dr. Belina Budini}

Head of the Communication and Public Relations Department at the European University of Tirana

\author{
Doi:10.5901/mjss.2015.v6n5s2p643
}

\section{Abstract}

It has always been a matter of general curiosity for the western media to look at the Balkans countries. In particular, the way how western media represent and construct those countries is also a question that has been taken by scholars generally. This paper shall look more closely at the American magazine, Time and the coverage it has given to Albania, one of the countries of the Balkans region. By focusing on one media and one country, the aim is to conduct a longitudinal study from the early days of Time publication to nowadays, precisely from the year 1923 to 2013, in order to grasp evolutional trends and developments over time. This study is based on a combined methodological approach from within the empirical tradition of the media studies and research: the textual studies and the study of the agency. Both quantitative and qualitative instruments are used to collect and analyze the data. The content analyzed consists of the news about Albania featured in Time magazine, in terms of their frequency, placement, topics and framings; as well as the language and the discourse used to depict the country, its people and its politics. Based on the above research, the main argument of this study is that the subject of Albania is approached and constructed in a repetitive constant way over time on the part of the Time magazine during the years 1923 and 2013.

Keywords: Albania media coverage, Time magazine, media construction of the Balkans, Discourse of an Albanian abnormality

\section{Introduction}

It has always been a matter of general curiosity for the western media to look at the Balkans countries. In particular the way how western media represent and construct those countries is also a question that has been taken by scholars generally. This paper shall look more closely at the American magazine, Time and the coverage it has given to Albania, one of the countries of the Balkans region.

I have chosen the magazine for two main reasons, both methodologically and strategically:

One is the generalist typology as a media, its periodicity and its important place in America and in the world, for its total audience reaches 25 millions that is the highest worldwide for a generalist magazine.

The second reason is that the subject of Albania in Time magazine allows for a longitudinal investigation, given that the data show a continual presence of the subject of Albania in its pages from the first year of publication and also for each period studied. Three are the chronological time periods studied here: 1923-1944, 1945-1989 and 1990-2013. Each period encompasses important and compact developments regarding both Albania and Time magazine.

The first period (1923-1944) relates to the aftermaths of the First World War and the Second World War that produced battlefields to be covered in the Balkans in general and Albania in particular, as can be seen under the rubric of the magazine: "Balkan Theater".

The second period (1945-1989) coincides with the Cold War and its significance both for America and Albania as "a country behind the Iron Curtain".

The last period, from the 1990-s to nowadays represents drastic changes with Albania free from isolation and toward democracy and the media internationally immersed in the digital revolution, while the USA as well as the rest of the world experienced the fall of the Berlin Wall, giving an end to the cold war myths in the press as well as in Time pages, but most lately the dramatic events of the Twin Towers assaults and the aftermaths of the war on terrorism..

Therefore, by focusing on one media and one country, the aim is to conduct a longitudinal study from the early days of Time publication to nowadays, precisely from the year 1923 to 2013, in order to grasp evolutional trends and developments over time.

The subject of Albania has been taken into account in this study as a state in its geographical, demographical, cultural, political, economic, social, cultural notions. Nevertheless, Albanians as a broader category including citizens in other states such as Kosovo, Macedonia or Albanian emigrants are not taken into account as units of analysis.

The criteria for the selection of the reports to be considered for analysis have been the presence of the term Albania referring to the above mentioned variants. Those terms are either retrieved from the headings and subheadings 
or the first paragraphs of Time magazine news.

\section{Methodology of the Study}

This study is based on a combined methodological approach from within the empirical tradition of the media studies and research: the textual studies and the study of the agency. Both quantitative and qualitative instruments are used to collect and analyze the data.

The content analyzed consists of the news about Albania featured in Time magazine, in terms of their frequency, placement, topics and framings; as well as the language and the discourse used to depict the country, its people and its politics.

The study of the agency builds mainly on interviews with the staff of Time magazine covering Albania.

Based on the above research, the main argument of this study is that the subject of Albania is approached and constructed in a repetitive constant way over time on the part of the Time magazine during the years 1923 and 2013.

Therefore, this paper shall endeavor to support the thesis that, in an evolutionary historical context, the topic of Albania in the western press, exampled in this study by Time magazine, remains approached and reported in a constant repetitive fashion. Its continuity and repetitiveness are imbedded in the language used in terms of key words and phrases, taglines, epithets, comparisons and other stylistic means of journalistic expression such as parody and irony. An important part is even present in the titles and subtitles.

Secondly, the quantitative data analyses show that the number of features published year after year, its classification in order of rubrics, topics, length, places, words and most mentioned personalities doesn't differ much either from one period of the study to the other.

Thirdly, the interviews with Time editors and their code of practices allow for some introspection linked to the theories of the social production of news and the social construction of the international news as well (Peter and Luckmann, 2011). This is to say that the press practices at Time particularly and its American institutionalization in terms of the production of foreign news (Tuchman, 1978), as well as American international relations in general influence its content or its approach towards distant and foreign countries like Albania (Wasburn, 2002).

\section{That "Small, Little, Tiny Country of Albania" of Time (1923-1944)}

\subsection{Quantitative data analysis}

The search in the digital data base of Time magazine produces 65 articles out of 253 results under the typing Albania for the period between April 1923 and July 1944, sorted by order of relevance, oldest or newest ${ }^{1}$. Those are only the selected reports where Albania is mentioned in the headings or in the first paragraphs. 31 out of the 65 features mention in their headings or their first paragraphs the name of Ahmet Zogu, the King of Albania during the period. Most of the reports appear under the rubric "Foreign Affairs News" and few others appear under Nation, War and Terrorism, Milestones, Religion and Letters. By comparison with other countries of the region during this time period, Albania is the country more frequently mentioned (253 times), while Serbia half of that (123 times), Montenegro mentioned in 65 reports, Macedonia in 47, Croatia in 68, even though they may be comprised also in a broader context, that of the term Yugoslavia mentioned in 533 articles. Countries like Greece, Romania and Bulgaria get mentioned more frequently, respectively in 975, 1021 and 464 reports.

The years of political instability such as the year 1924 when Albanian governments went up and down, got most reports with 7 during this same year. The year 1927 when Albania and Italy were together in the Treaty of Tirana is also the year when the subject gets more attention with 8 reports. Even though the number of features is relatively high, the length is limited with only 6 long ones (above 1000 words), 8 medium (400 to 800 words) 49 short and one cover story. Surprisingly most of the news features, 38 out of 65 , appear in the context of internal development in Albania and 25 out of 65 in the context of international relations such as the World War Two. However, the chronics about the king Ahmet Zogu comprises e large part of the internal developments reports. 10 out of 38 reports gossip around his private life, his habits and his bachelor status, his mistresses, his sisters, his son and the queen Geraldine Appony.

Among the most mentioned personalities of this period appear, apart from Ahmet Zogu, namely Faik Konica and Fan Noli, all three politicians and officials of the Albanian state. It is interesting that the King of Albania has been mentioned twice as many as Coco Chanel during this period with other statesman like Churchill, Roosvelt, Gandhi and

${ }^{1}$ All the data are retrieved by at least September 2014. 
the dictators Hitler, Mussolini and Stalin on the top. James Joyce, Pablo Picasso and even Charlie Chaplin or Albert Einstein are among the least mentioned, if we compare them with the above political man.

Geographically speaking, the coverage doesn't go far from the administrative centers of the capital Tirana, the ports of Durres and Valona, with only episodically mentioned few other cities such as Argirocastro, Tepeleni or Mati and Scutari in the context of war battlefronts.

\subsection{Qualitative data analysis (The discourse and language)}

The texts analyzed in this paper referring to the meaning of the language used confirm a discourse of abnormalities. This discourse is largely present as a way of constructing the narratives and the story lines, as well as openly exemplified in the headings, first paragraphs and subtitles of the stories about Albania. This language is characterized first by extreme schemata relating to the territory, but even to the climate, to the people, to the nation, etc. The taglines for Albania almost in all the reports are small, tiny or little Albania and its variants such as the smallest country, the pocket-size country, the very little kingdom. Often the extreme is reinforced as in the example "the smallest nation in the Balkans" that relates to Albania as the smallest of the smallest ${ }^{2}$. The language of extremes relates also to the climate, to the poverty as well as to the political developments and to the political leaders. In a report of the 11 January 1937, Tirana, the capital of Albania has been described as "the worst hole in Europe" in the phrase: "Tirana, the mountainous little kingdom's capital, is regarded among diplomats as the worst hole in Europe"3. The Time report on Albania on the 21 of March 1927, depicts Tirana as "that little, vile, ill-favored capital"4. The extreme language goes on with other depictions such as in the phrase "The almost rural silence of Tirana, the small capital perched in the mountains of the tiny Kingdom of Albania". In other reports Time mentions the "wild mountains behind Tirana"6, or "Through the jagged mountains of Albania"7 in a report referring to the extreme reliefs as well as in the phrase "the mountains peaks and troughs of perpendicular little Albania" in another report ${ }^{8}$. In a long report that dates 17 April 1939 Time depicts Albania as "Most primitive and out-of-the-way spot in Europe, most Oriental than Western..."'. Referring to its size again, in a report of the 1924, Time writes "Albania (about the size of New Jersey plus Maryland"10. As to the Albanian people Time writes "Albanians: filthy, wretched, impoverished, fly-bitten, famine starved and earthquake stricken" in a report titled "Albania, President into King" that gives a contrast between the state of Albanian people and the King Ahmet Zogu'11. Moreover he is referred to as the "Bachelor King", "Little King Zog", "His smart little majesty king Zog", "Footlose Zog", "Lonely King Zog", "Hoarse-voiced King Zog", etc.

The journalistic style of Time writing is famous for its colors, boldness and parody, especially during the years studied here. Albania gets it all as a subject, but most of all is characterized by parody. Headings such as "Albania: Footlose Zog", or "Albania: Zog and Jerry" or "Albania: International Cough", "Albania: Swiss Laws, Greek Patriarch" are parodies in themselves. The body of the reports offers other colorful parodies such as in the constructs referring to Albanians as "fierce-faced... hoped on scrawny donkeys"12 or "baggy-trousered clansmen"13. In other expressions, Time refers to Albania as "That sharp spur-wheel, Albania: or as "ready to be prodded" (International: Scared, 28 March 1927). Ahmet Zogu himself is often the favorite subject of parody when it is called freely "bachelor king", "footloose Zog", "Italy's puppet", "His smart little majesty King Zog", "hog-tied (with a crown), "lonely King Zog" or "hoarse-voiced King Zog"14.

In a longer version Time refers to him as follows: "Though Albania may lack roads, she should never lack for royal palaces. Last week Italian workmen and engineers, sent by King Zog's patron and protector, Dictator Mussolini, laid the foundations of a new royal palace, Zog's fifth outside the grimy old capital city of Tirana..." and below: "Albanians recalled

\footnotetext{
2 Time magazine, "Albania: a noose for Benito", 7 June 1943

3 Time magazine, "Albania: Fatima or Else", 11 January 1937

4 Time magazine; "Albania: Agent Provocateur", 21 march 1927

5 Time magazine, "Albania: Birth and Death" of the date 17 April 1939

6 Time magazine, "Albania: a noose for Benito", 7 June 1943

7 Time magazine, "Zog's Choice", 7 February 1938

8 Time magazine, "Balkan Theatre: Children of Socrates" published on the 9 May 1938

9 Time magazine, "Albania: Birth and Death", 17 April 1939

10 Time magazine, "Albania: Man Sized Revolt, 23 June 1924

11 Time magazine, "Albania, President into King", 27 August 1928.

12 Time magazine, "Zog and Jerry", 9 May 1938.

13 Time magazine, "Albania; a nose for Benito", 7 June 1943

14 Time magazine, Albania: International Caough, 8 July 1929; "Albania; Supreme Removal", 21 March 1932; "Footlose Zog," 19 June 1933; "Milestones", 27 January 1936; "Albania: Fatima or Else", 11 January 1937; or "Italy: Lost and Found, 3 October 1938.
} 
that at the time of King Zog's coronation last year, only one expresses intention of genuine Scanderbeg descendants to slit Zog's royal gullet dissuaded the new King from adopting the title of Scanderbeg II"15.

\section{Albania, "A Glimpse Behind the Iron Curtain" from Time (1945-1989)}

\subsection{Quantitative data analysis}

The second period from the year 1945 to 1989 is dominated by the communist dictatorship of Enver Hoxha. The quantitative data show fewer results for Albania for this period, with only 54 dedicated reports out of 337 largely mentioning it. 49 of the reports pertain to the rubric World and the rest to rubrics Nation, People, Milestones, To our readers and Arts and Entertainment. The isolation of the country constitutes a topic of its own for Time magazine to report on, but only in exceptional cases the journalists have succeeded in entering communist Albania. Yet, compared to other neighbor countries like Montenegro, Macedonia and further ones like Serbia and Croatia, the subject of Albania is more present. It is clear that these countries appear more often under the federate state of Former Yugoslavia mentioned in more than 1500 report by and large. As Albania is mentioned in 337 reports, Montenegro is mentioned in 47 reports, Macedonia in 5, Croatia in 29 and Serbia in 44. However, Bulgaria, Romania as well as Greece and Italia receive much more coverage. Angela Leuker, former administrator at the Vienna Office for Time magazine during the '80-s, in an interview for this study said that the magazine didn't have many resources in covering the region of the Balkans and that the official sources coming from state agencies were untrustworthy and full of ideologies. Especially for Albania, entering the country was quite impossible ${ }^{16}$. The editor at the Vienna Office for the Eastern, Central and Southeastern Europe, James Graff also states that the coverage of Albania was low during this period and that this is also linked to the shift in interest for Time magazine and the American media in general. The human rights and the Vietnam War, not Europe after the World War Two were the subjects of the day.

Nevertheless, the content analysis based on the quantitative data show that the placement of the subject of Albania in the hierarchy of the magazine is most often respectable. Rarely covered, but when it happens, the report is on the top of the rubric World, as most newsworthy. World was the second most important rubric in Time right after Nation ${ }^{17}$.

It is evident that there were fewer reports on Albania published during this period in Time magazine, as well as the subject was developed at length. 10 out of the 54 reports, were long (superior to 1000 words), 23 were medium between 400-800 words, and 21 were short features with less than 400 words.

The thematic classification shows the prevalence of internal affairs as a more frequent angle rather than the reference to Albania in the context of international developments. This is not to say that the international references are lacking. They still prevail in 24 reports, whereas 30 others refer to internal affairs of Albania. 5 reports out of 24 refer to United Nations, 10 to international communism, 5 to developments in the Balkan region, 3 as international diplomatic topics and 1 as political literature.

The interest of Time in political figures doesn't change either for this period. With the exception of Mother Teresa, no other nonpolitical Albanian figure does appear in Time magazine pages for this period. However, Enver Hoxha, the dictator, surpasses Mother Teresa, because he appears in 39 reports versus Mother Teresa who is mentioned in 21 reports. As Albanian, she is mentioned only 4 times. All other mentioned Albanian figures are politicians from Mehmet Shehu, the prime minister under Enver Hoxha regime to Ramiz Alia, the president after the death of Hoxha, but also Hysni Kapo, Panajot Plaku, Koci Xoxe and finally Liri Belishova, mentioned once in the context of the relations with the former URSS. Only after the ' 90 -s does a prominent nonpolitical figure like Ismail Kadare, appear in Time magazine.

Even the geography of the reports is poorer for this period, related to Albania. Only Tirana, the capital gets mentioned frequently, in 42 reports precisely, Durazzo in 3, Valona in 5 and Scutari mentioned once. Because of the isolation of the country, most often Time refers to places like "somewhere in Albania"18.

\footnotetext{
15 Time magazine, "Albania: Zog, not Skanderbeg", 17 June 1929.

${ }^{16}$ Interview with Angela Leuker. She as administrator and reporter of support for the Vienna Bureau at Time Magazine, from the year 1986 to 2006. Interviewed for this study on the 3 February 2014.

${ }_{17}$ See articles first in row like "Eagle's Country: The Land they are fighting over", 27 October 1961; "Albania, Benighted Nation", 10 August 1962; "Albania: Enver Hoxha: 1908-1985 Stalin's Disciple", 22 April 1985; "Albania. The Eagle spreads its wings", 1 December 1986 . And other second in row like "United Nations: Such interesting people" 3 March 1947; "Communists, a swim in the Adriatic" or third like "Albania: Odd Man Out", 24 October 1960; "Albania: Pay now, work later", 13 July 1970 or "World: East Bloc: Illusions of unity", 29 December 1980, to name but a few.

${ }^{18}$ See for example: "Communists: Battle for the backyards", 4 April 1969.
} 


\subsection{Qualitative data analysis (The discourse and language)}

The textual data in terms of the language, the style and the way Albania is depicted by Time Magazine, reinforce the discourse of abnormality for this period, discourse that gets more profound and gains continuity for the future decades to come. Abnormal characteristics are attributed to the people, the places and the natural features of Albania as during the first period and for this period they are even more pronounced in the style of the communist regime and its representatives. What is more evident, the extreme schemata constitute the way of seeing Albania in almost every aspect and repetitively as "the tiniest, the poorest, most backward country"19. The taglines for Albania remain unchanged with its size mentioned in almost all the reports in the variants "the tiny", "the little", "the small", "the pocked-sized". Extremities of the size are often associated with other extreme characteristics such as in the phrase: "Pocked-size Albania has always been the most backward of the Iron Curtain countries ${ }^{20}$. In another report Time states that "Albania is the tiniest, the poorest and most backward of all communist satellites in Europe and the only one that has no common border with another state in the U.S.S.R's empire"21. Further on, the enmeshed extremities go hand in hand as in the phrase "The tiny nation that Russia and Red China are using to work off their ideological aggressions, is tucked away in a remote corner of the Balkans" (Eagle's country: The Little Land they are fighting over, 27 October 1961).

In another report, the extreme of the extremes is depicted as follows: "Like Dante's Inferno, Communism has its different levels of horror and misery. At the bottom of the pit, by almost any measure, lies Albania..."22.

Similar depictions were also present in a report of the 1951 that declares: "Albania is the most obscure, backward and isolated country behind the Iron Curtain"23. In another report Time writes that "Life in Albania can be brutish, nasty and short. 14 concentration camps and dozen jails are jammed with an estimated 30000 prisoners - nearly $2 \%$ of the total population"24. Such depictions are not exceptional and Albania is continuously referred to as a "benighted nation"25, "rugged country"26, "rocky road"27, "The weakest Soviet satellite"28, "The only satellite isolated from Moscow by unfriendly territory"29, "satellite Albania, Soviet Communism only Mediterranean base"30, "Albania: the black sheep"31, "the most wretched country in Europe"32, "the least accessible nation in the communist world today"33, "a minute, mountainous country... poor in living conditions, rich in anachronisms and completely alone in its bizarre comradeship with Red China..."34, "the little Balkan dictatorship"35, "puppet state of Albania"36 or "China's sole friend in Europe... and for the last decade it has been as angry and insulated as Peking itself"37, "It is Europe's poorest nation and one of the world's most closed societies"38.

The list gets long, but the colorful exceptional depictions continue as in the phrase: "It is a pedestrian heaven; Albania is quite possibly the most earless country anywhere. The people are suspicious, curious, unsmiling- testimony to the effectiveness of Party Boss Hoxha's moto: "It is fear that guards the vineyard"39. In another report, years latter, Albania is depicted as "an isolated, mountainous country of 2,9 million people, is a place of bleak statistics. It is Europe's poorest nation and one of the world's most closed societies. Its harsh internal policies place it among the last bastions of

\footnotetext{
19 Time magazine, "Communists: a swim in the Adriatic", 8 June 1959

20 Time magazine, "Albania: Down goes Hoxha", 2 August 1954

21 Time magazine, "Communists: a swim in the Adriatic", 8 June 1959

22 Time magazine, "Albania, Over the Hill, 3 June 1957

23 Time magazine, "Albania, By remote control, 14 May 1951

24 Time magazine: "Albania: Death to the Muscovites, 28 April 1961

25 Time magazine, "Albania: Over the Hill", 3 June 1957

26 Time magazine, "Albania: Over the Hill", 3 June 1957

27 Time magazine, "Albania, the rocky road", 19 July 1954

28 Time magazine, "Albania: a New Stooge", 17 April 1950

29 Time magazine, "Albania, Down goes Hoxha", 2 August 1954

30 Time magazine, "The Mediterranean: Out of the North, 29 July 1957

31 Time magazine: "Albania: the black sheep", 23 June 1961

32 Time magazine, "Albania, Benighted nation", 10 August 1962

33 Time magazine: "Albania, Lock on the Dore, 26 May 1967

34 Time magazine: "Albania, Lock on the Dore, 26 May 1967

35 Time magazine: "Albania: Emulating Mao, 23 February 1970

36 Time magazine: "China: Don't fence Mao in", 26 May 1967

37 Time magazine: "The World: Fear that guards the vineyard", 6 September 1971

38 Time magazine: "Albania, Enver Hoxha: 1908-1985, Stalin Disciple, 22 April 1985

39 Time magazine, "The World, Fear that guards the vineyard, 6 September 1971.
} 
Stalinism"40. A report of the late years of the dictatorship, after Hoxha's death, cites: "Known to his citizens as the "land of the Eagle" Albania is notable in two dubious counts: it is Europe's poorest nation and a relic of the Stalinist era" (Albania: The Eagle spreads its wings, 1 December 1986). In another report the exceptionality is depicted in a more lightweight style: "Last week Communist Albania accomplished an astonishing record: almost perfect parliamentary elections. Every one of the country's 1, 830, 653 registered voters cast a ballot, and all candidates selected by the Albanian Labor Party won $100 \%$ of the votes counted. But alas, a single ballot was declared invalid by officials. Wait till next year"41. The last report for this period marks again the exceptionality of the size in the phrase: "A Maryland-size slice of the Balkans, The People's Socialist Republic of Albania has for more than three decades peeped warily at the world from behind a stiff veil of Marxist-Leninist rigidity"42.

The depiction of Enver Hoxha is not without contrasts and contradictions when Time in early reports describes him smoothly as "handsome Hoxha", "spunky fellow", "hulking, baby faced", "truculent as a small boy", "Albania's youngish (38) dictator", Enver Hoxha (rhymes with got-cha)", whereas latter on continues to describe him quite neutrally as "Albania's party boss Enver Hoxha". Only after his death, Time calls him "doctrinaire dictator Enver Hoxha". He once was even admired in a report by Time: "So he [Enver Hoxha] permitted free and secret balloting, under a system rude but effective. It functioned admirably". In another report he gains also a mostly favorable account from Time: "This same national touchiness is continually displayed by Red Boss Enver Hoxha, and represents much of his strength. Albanians have a Mediterranean fondness for florid and denunciatory speeches, and Hoxha is recognized even by his enemies as a master of this sort of oratory. Tall and handsome, with thick, pomaded hair now greying at the temples, Hoxha draws stormy applause for his insults to Khrushchev. Hoxha's picture is plastered on just about every wall in the land. His profile adorns Albania's monetary unit, the lek, and at meetings of the Communist Central Committee (most of whom are related to each other and to the boss by blood or marriage) Hoxha speaks from a podium decorated with a plaster bust of himself. Like his country, Hoxha is full of surprises. Instead of being a rough, tough mountain chieftain, he is a former schoolteacher and was the pampered son of a well-to-do Moslem merchant. Though he has the mentality of a brigand, his manners are those of a cultivated bourgeois and reflect his education at universities in France and Belgium"43.

This same romanticized depiction applies to other Albanian politicians like Hysni Kapo who is referred to as "Albania's Kapo... wearing a celluloid collar, his hair slicked down like a dancehall Romeo's"44.

As an exception appears in Time even the prime minister Mehmet Shehu who is referred to as "Among the gaggle of satellite Communist bosses trotting at Nikita Khrushchev heels in Manhattan, one was conspicuously odd man out. Red Premier Shehu of Albania..."45.

The famous Timestyle with its characteristic writing remains dominant in the reports about Albania for this period as well. The parody is found in almost every report, obvious in the headings, but also in the details and narrative constructions of the reports. As an example, the parody as a way of constructing the narrative about Albania is evident in this paragraph from a report on the relations between Albania and China:

"But even the somber Chinese seemed to be displaying a sense of humor in the matter of Albania. Peking's People's Daily declared that the "comradeship in arms" between China and Albania "is as deep as the Adriatic and as sublime as the Himalayas." The Himalayas are sublime, all right, but the Adriatic Sea, which washes the shores of Albania, is notorious for its shallowness"46.

It is also with parody and irony that Time reports about elections in Albania in 1987:

"Last week Communist Albania accomplished an astonishing record: almost perfect parliamentary elections. Every one of the country's 1,830,653 registered voters cast a ballot, and all candidates selected by the Albanian Labor Party won $100 \%$ of the votes counted. But alas, a single ballot was declared invalid by officials. Wait till next year. ${ }^{247}$

The parody with Ahmet Zogu, one of Time's favorite personalities to be covered even when he wasn't king anymore, continues in a report all parody that calls him: "

\footnotetext{
40 Time magazine, "Albania, Enver Hoxha: 1908-1985, Stalin Disciple, 22 April 1985

41 Time magazine, "Albania: what could be more perfect?", 16 February 1987

42 Time magazine, "Albania: Borrowing from the past, 4 December 1989 (Time Europe)

43 Time magazine, "World: Albania: Stalin Heir", 22 December 1961

44 Time magazine, "United Nations, Such interesting people, 3 march 1947

45 Time magazine, "Albania: Odd Man Out, 24 October 1960.

46 Time magazine "Communists: Independent Dummy", 11 December 1964

47 Time magazine, "Albania: What could be more perfect?", 16 February 1987
} 
“...over his tiny kingdom of Albania, former King Zog... Short on cash, Zog"48

\section{Repetitive Albania of Time, After the Fall of Communism (1990-2013)}

\subsection{Quantitative data analysis}

The period from the year 1990 nowadays is marked by relevant developments both for Time magazine and Albania. During this period the magazine itself diversifies and the reports appear in an online publication from the year 1997, namely Time.com, as well as in the alternative publications of Time Europe, Middle East and Africa or Time Asia, whereas the core of it all is of course Time US.

Neither the subject of Albania is properly unified for this period with the war on Kosovo that produced a second Albanian subject for the public of the international news media. The events in Macedonia as well are often linked to the Albanian factor in the Balkans. However, this study sticks to Albania solely.

Therefore, the quantitative data show that 49 is the number of the reports that approach directly the subject of Albania in Time magazine for this period with 25 reports that appear in Time US, 19 in Time.com, 3 in Time Europe, Middle East and Africa, 2 others in Time Asia. The years with most reports are the '90-' 91 as the fall of the communist regime, the '97-'99 period with dramatic developments after the fall of the pyramid schemes and the 2007-2013 with events related to USA themselves like the visit of the former American president, George W. Bush to Albania and the destruction of Syria chemical arms involving USA and Albania in negotiations.

Comparing to the two first periods with accordingly 63 and 54 reports, the number of 49 reports for this last period shows a fall in coverage. Even though the periods do not compound equal number of years, the tendency is toward less coverage regarding Albania as well as international coverage in general at Time magazine during this period. The diversified media like Time Europe or Time Asia and the online media like Time.com do not add much either.

Angela Leuker, former administrator at Time magazine, the Vienna Office, from 1983 until 2006, tells about a small bureau centered in Vienna that covered both Central Europe and the Balkans ${ }^{49}$. The chief of the office, James Graff (1990-1995) tells that the events in the Balkans were important during these years and that he travelled to Albania by himself in the first year to cover the first free elections in the country. However, when it comes to the number of reports on Albania that indicates a limited coverage, Graff tells that Time and almost all other publications in USA have drastically shortened the staffs not only internationally but also in the country. "I have served as Chicago Bureau Chief in the mid till the end of the '90's and Time doesn't have an office there anymore either... I have been to Octavo, Vienna, Brussels, Paris, London, but in two of these cities, in Octavo as well as in Brussels I have not been replaced by anyone. For more than a decade the office in Vienna doesn't operate anymore and there will bee no more a Time office there..." 50

There is also a tendency of a fall in the coverage of Albania in comparison to other countries of the region. For example Serbia gets 835 reports whereas Albania only 264 (both of them broadly mentioned, not as first subjects of content). Only compared to Montenegro and Macedonia, Albania still prevails. An Albanian freelancer and stringer at Time Magazine, Altin Raxhimi, tells that the first years of the '90's were the "flourishing" ones in coverage with Albania entering the subject of Kosovo events as well and the logistics that Time had in place in the region naming the most important members of the editorial offices in Europe like Massimo Calabresi, James Graff, but also the war correspondent Edward Barnes, as well as other senior correspondents like Sarah McLeary, without mentioning the supporting staff like drivers, fixers and stringers... Not anywhere close to CNN but still quite an army..." 51.

Massimo Calabresi, the chief editor of the Vienna Office after Graff left office and Edward Barnes, a senior war correspondent for both Time and Life magazines, tell that the interest in Albania was especially high during the war events and that the coverage at the time was very expensive ${ }^{52}$.

Even though the number of reports is relatively small for this period, the place given to the subject of Albania in the

48 Time magazine, "People; Pleasures and Palaces", 1 October 1951

49 Interview with Angela Leuker, administrator and supporting reporter for the Vienna Bureau at Time Magazine from 1986 to 2006. Interviewed for this study the 3 February 2014.

50 Interview with James Graff, former editor and Bureau Chief at Vienna Bureau, responsible for the coverage of the Central Europe and the Balkans during 1990-1995. Interviewed for this study the 3 February 2014.

${ }^{51}$ Interview with Altin Raxhimi, freelancer and former stringer and Albanian collaborator at Time magazine (1999-2011). Interviewed for this study the 3 February 2014.

${ }^{52}$ Massimo Calabresi, the chief editor of the Vienna Office responsible for the coverage of the Central Europe and the Balkans during 1995-1999. Travelled to Albania and covered the 1997 events as well as the war on Kosovo. Interviewed for this study the 3 February 2014. 
rubrics order is still important. The data shows that the reports on Albania constitute the first, the second or at least the third order of the rubrics and never the last. This is seemingly favored by the alphabetic order as well that puts Albania first when this applies.

The words count tells shorter reports for this period with 30 among them with less than 400 words, 3 long, above 800 words. The rest are medium size reports, between 400 and 800 words. The reports on Kosovo take the most important coverage in terms of frequency and both length.

The reports on Albania appear under the rubrics World, Letters, Entertainment and National or Politics, but most of them in the World section of the magazine. Few pictures appear in the version online Tim.Com and very few in the Time US to be considered for analysis.

The topics were mainly internal politics, democratic changes, conflicts and turbulent events, international relations and less so Albanian phenomena or social stories.

Massimo Calabresi, actual editor at Time for the Washington Bureau and former chief editor at the Vienna Office tells for this study that they were constrained to limit the number of stories and to be very selective bearing in mind the fact that the publication is weekly and that the staff was much more limited than that of the dailies ${ }^{53}$.

One of the most mentioned Albanian figures for this period is Sali Berisha, as leader of the Democratic Party during the ' 90 's, as prime minister and president, the politician who has marked the period as a whole with its presence. Berisha comes third in the comparative data with 16 mentions in the selected reports, after Enver Hoxha (mentioned in 48 reports), Ahmet Zogu (in 33 reports). Other most mentioned Albanian figures are Mother Teresa (65), Ibrahim Rugova (29), Hashim Thaci (17), Ramush Haradinaj (5) and Gjon Mili, an Albanian photographer that worked for Life magazine, mentioned in 20 reports. Regarding the most mentioned geographical places, Tirana remains always on the top with other cities such as Fushe Kruja for the first time in the context of the surprising visit of the former president to the town.

\title{
5.2 Qualitative data analysis (language and discourse)
}

There is a discourse of anarchical Albania in place for this period at Time magazine with repetitive crises, chaos and turbulent events. This is to say that overall the textual analysis tell again the discourse of an Albanian abnormality. The reports on the events right after the fall of the communist regime in the ' 90 's, as well as the episodes of the economic crises after the fall of the pyramid schemes in the year 1997 and the political events of protests like that of the 21 January 2011 constitute a large part not only of the occasions to write about Albania, but also to construct the subject as an exception, with the extreme depictions still dominant. For example in a report of the early days Time writes: "Paranoid, reclusive Albania is beginning to reach out and touch someone. The nation opened telephone links with 54 Western countries..." 54

\begin{abstract}
Albania continues to be referred to as the poorest, the tiniest, the most isolated as a rudiment of the dictatorship years as shows this report of 1991: "Despite their landslide victory in Albania's first free elections last spring, the old communist rulers have had trouble holding on to power as the wave of reform sweeps over Europe's poorest and most isolated country"55
\end{abstract}

The serial of depictions as exceptionality continues as the below example shows: "Only one Communist government in Europe managed to withstand the political earthquake unscathed. Now, nearly six months later, the leadership of Tiny Albania is finally loosening its ultra-orthodox Stalinist grip" 56

Speaking of violence and crisis, here it goes in another report from the same year:

"Though the communists won a commanding 162 of the 250 People's Assambley seats... their victory ignited some of the worst violence the country has seen in more than a year of escalating unrest" 57

The repetitive features attract Time magazine coverage years latter in the same fashion with more synonymies:

"Foreigners flee as tiny Albania dissolved into Mad Max-Style Chaos"58

\footnotetext{
53 ibid

54 Time, "Grapevine, 14 maj 1990 (Time US)

55 Time, "Albania: A setback for the Old Guard, 16 December 1991 (Time US)

56 Time, "Albania and then there were none, 21 May 1990 (TIME US)

${ }^{57}$ Time, "Albania: It's not over by a long shot, 15 April 1991(Time US)

58 Time, No Law or Order in the Land, 24 March 1997 (TIME US)
} 
This dramatic depiction is described as following: "Europe looked to its southeast last week to find civilization vanishing down a sinkhole. Perennially under priviledged Albania suddenly was no longer an organized society but a state of chaos... [...] what had begun as spontaneous revolts in a few southern cities turned all of the country into a Mad Max movie: children brandishing grenades and automatic rifles; wholesale looting; and frenetic, random gunfire- an utter collapse of civil authority. Small, sun-washed Albania had become the state of Anarchia"59

Continually referred to as "tiny Albania" the tagline doesn't change for this period either as in the below citation from Time.com publication: "Tiny Albania emerged from communist dictatorship in 1990 only to tumble into a rough world of gangsters, fraudulent financial machinations and incompetent governance, exacerbated by laëless capitalism and devil-may-care politics"60

The other epithets are also retaken like "remote country" or "the poorest" as in the below fragment from a report on the visit of former American president in Tirana: "Bush will be the first sitting president to visit the remote Balkan country, the poorest in Europe, and Albanians have outdone themselves in preparations: tens of thousands have thronged to the run-down capital, Tirana, to get a glimpse of the American first couple"61

Again the protests and the political unrest come as primary subject in an article that states: "The scandal was enough to spark last week's protests, the most violent the country has seen in almost 15 years"62

Even the political figures are referred to in case they represent an exception as in the fragment below: "[Edi Rama] used his outsized personality (and physique) to transform his hometown and, with it, much of the country's politics."63

Another political protagonist, Leka Zogu is depicted in an exotic fashion like in the fragment below: "Bonus Royal Factoid: In the 1960s, the self-styled royal [Leka Zogu] struck up a friendship with Ronald Reagan. As a gift, he sent the future U.S. president a baby elephant named Gertie-a moniker deemed unrefined by Nancy Reagan, who rechristened the animal «GOP.» 64

Finally the former queen, Geraldine Appony continues to be refereed to as: "Queen Geraldine of the Albanians, 87, widow of King Zog [...] known as "The White Rose of Hungary", this former aristocratic beauty..."65

Regarding the style of writing, the famous Timestyle is revived during this period, especially in the Time US edition, whereas the online version is more direct and simple, adapted to a different kind of medium means of expression and audience habits.

So as to the parody, it still remains important as a way of reporting and constructing the narratives about the subject of Albania. It is found in the titles such as "Campaigning, Albanian-style" or "Albania: Please Occupy us", or "Albania, revolution by balloon", "Albania: Duty free for all", "Albania: Don't wear your tuxedo in Tirana", etc.

\section{Conclusions}

Based on the above research, the main argument of this study is that the subject of Albania is approached and constructed in a repetitive constant way over time on the part of the Time magazine during the years 1923 and 2013.

Therefore, this paper tried to support the thesis that, in an evolutionary historical context, the topic of Albania in the western press, exampled here by Time magazine, remains approached and reported in a constant repetitive fashion. Its continuity and repetitiveness are firstly evidenced in the language used in terms of key words and phrases, taglines, epithets, comparisons and other stylistic means of journalistic expression such as parody.

Secondly, the quantitative data analyses showed that the number of features published year after year, its classification in order of rubrics, topics, length, places, words and most mentioned personalities, places and type of events didn't differ substantially for each period.

Thirdly, the interviews with Time editors and their code of practices allowed for some introspection linked to the theories of the social production of news and the social construction of the international news as well. This is to say that the press practices at Time particularly and its American institutionalization in terms of the production of foreign news, as well as American international relations in general influences its content or its approach towards distant and foreign countries like Albania.

Borrowing from a Time magazine report on the Balkans, Albania together with other countries are described as

59 Time, No Law or Order in the Land, 24 March 1997 (TIME US)

60 Time, "The Trouble with Democracy: Albania's Worrisome Vote, 21 May 2011 (Time.com)

${ }^{61}$ Albania: "Please Occupy Us!", 10 June 2007 (Time.com)

62 Deadly Protests Don't End Albania's Power Play, 28 January 2011 (Time.com)

${ }^{63}$ A Mayoral Makeover, 2 October 2005 (Time.com)

64 Life after the throne, 5 January 2008 (Time.com)

65 Milestones, 28 October 2002 (Time Europe, Middle East and Africa) 
follows: "The crowded area known as the Balkans have exploded regularly in unspeakably cruel wars... in the process, the Balkans: Yugoslavia, Rumania, Bulgaria, Albania, Greece and the European part of Turkey, became famous as a scene of intrigue and espionage" ${ }^{66}$. It comes as a conclusion, in fashion with the title of the above report that the "old script" is not easily changed and so it doesn't in the case of Albania.

\section{References}

Berger Peter L. Luckmann Thomas, The Social Construction of Reality: A Treatise in the Sociology of Knowledge, Open Road Media, 2011.

Philo C. Wasburn, The social construction of international news, We're talking about them, they're talking about us, London: Greenwood Publishing Group, 2002.

Tuchman Gaye, Making News: a Study in the Construction of Reality: Free Press, 1978.

Time magazine, "Albania: a noose for Benito", 7 June 1943

Time magazine, "Albania: Fatima or Else", 11 January 1937

Time magazine; "Albania: Agent Provocateur", 21 march 1927

Time magazine, "Albania: Birth and Death" of the date 17 April 1939

Time magazine, "Albania: a noose for Benito", 7 June 1943

Time magazine, "Zog's Choice", 7 February 1938

Time magazine, "Balkan Theatre: Children of Socrates" published on the 9 May 1938

Time magazine, "Albania: Birth and Death", 17 April 1939

Time magazine, "Albania: Man Sized Revolt, 23 June 1924

Time magazine, "Albania, President into King", 27 August 1928.

Time magazine, "Zog and Jerry", 9 May 1938.

Time magazine, Albania: International Caough, 8 July 1929;

Time magazine, "Albania; Supreme Removal", 21 March 1932

Time magazine, "Footlose Zog," 19 June 1933;

Time magazine, "Milestones", 27 January 1936;

Time magazine, "Italy: Lost and Found, 3 October 1938

Time magazine, "Albania: Zog, not Skanderbeg", 17 June 1929.

Time magazine, "Eagle's Country: The Land they are fighting over", 27 October 1961

Time magazine, "Albania, Benighted Nation", 10 August 1962;

Time magazine, "Albania: Enver Hoxha: 1908-1985 Stalin's Disciple", 22 April 1985; Time magazine, "Albania. The Eagle spreads its wings", 1 December 1986

Time magazine "United Nations: Such interesting people" 3 March 1947;

Time magazine, "Albania: Odd Man Out", 24 October 1960

Time magazine, "Albania: Pay now, work later", 13 July 1970

Time magazine, "World: East Bloc: Illusions of unity", 29 December 1980

Time magazine, "Communists: Battle for the backyards", 4 April 1969

Time magazine, "Communists: a swim in the Adriatic", 8 June 1959

Time magazine, "Albania: Down goes Hoxha", 2 August 1954

Time magazine, "Albania, Over the Hill, 3 June 1957

Time magazine, "Albania, By remote control, 14 May 1951

Time magazine: "Albania: Death to the Muscovites, 28 April 1961

Time magazine, "Albania: Over the Hill", 3 June 1957

Time magazine, "Albania, the rocky road", 19 July 1954

Time magazine, "Albania: a New Stooge", 17 April 1950

Time magazine, "Albania, Down goes Hoxha", 2 August 1954

Time magazine, "The Mediterranean: Out of the North, 29 July 1957

Time magazine: "Albania: The black sheep", 23 June 1961

Time magazine, "Albania, Benighted nation", 10 August 1962

Time magazine: "Albania, Lock on the Door, 26 May 1967

Time magazine: "Albania: Emulating Mao, 23 February 1970

Time magazine: "China: Don't fence Mao in", 26 May 1967

Time magazine: "The World: Fear that guards the vineyard", 6 September 1971

Time magazine: "Albania, Enver Hoxha: 1908-1985, Stalin Disciple, 22 April 1985

Time magazine, "Albania: what could be more perfect?", 16 February 1987

Time magazine, "Albania: Borrowing from the past, 4 December 1989 (Time Europe)

Time magazine, "World: Albania: Stalin Heir", 22 December 1961

${ }^{66}$ Time Magazine, "The Balkans: Changing the Old Script", 29 November 1971 
Time magazine, "United Nations, Such interesting people, 3 march 1947

Time magazine "Communists: Independent Dummy", 11 December 1964

Time magazine, "Albania: What could be more perfect?", 16 February 1987

Time magazine, "People; Pleasures and Palaces", 1 October 1951

Time magazine, "Grapevine", 14 May 1990 (Time US)

Time magazine, "Albania: A setback for the Old Guard", 16 December 1991 (Time US)

Time magazine, "Albania and then there were none", 21 May 1990 (TIME US)

Time magazine, "Albania: It's not over by a long shot, 15 April 1991(Time US)

Time magazine, "No Law or Order in the Land", 24 March 1997 (TIME US)

Time magazine, "The Trouble with Democracy: Albania's Worrisome Vote", 21 May 2011 (Time.com)

Time magazine, "Albania: "Please Occupy Us!", June 2007 (Time.com)

Time magazine, "Deadly Protests Don't End Albania's Power Play", 28 January 2011 (Time.com)

Time magazine, "A Mayoral Makeover", 2 October 2005 (Time.com)

Time magazine, "Life after the throne", 5 January 2008 (Time.com)

Time magazine, "Milestones", 28 tetor 2002 (Time Europe, Middle East and Africa) 